\title{
PENGARUH FAKTOR INTERNAL DAN EKSTERNAL PERUSAHAAN TERHADAP YIELD TO MATURITY OBLIGASI KORPORASI YANG TERDAFTAR DI BURSA EFEK INDONESIA
}

\author{
Augustpaosa Nariman \\ Fakultas Ekonomi Universitas Tarumanagara Jakarta \\ Email:augustpaosa@yahoo.com
}

\begin{abstract}
This research is to analyze and obtain empirical evidence about the influence of internal factors and external factors on the yield to maturity of corporate bonds. Internal factors are the company's audit committee, company size, debt to equity ratio while the external factors is the quality of auditors and the interest rate of Bank Indonesia. This research usedsample of 33 companies which issued bonds in 2011-2013. Data were analyzed using multiple linear regressionand prior to hypothesis testing has been performed classical assumption test. Result obtained from the research shows that the internal factor which consist of the audit committee, company size, and debt to equity ratio are not significantly affects the yield to maturity of the bonds. Size companies shows the results of a negative influence on the yield to maturity of the bonds. External factors, namely the quality of auditors and Bank Indonesia interest rate are significantly affects the yield to maturity of the bonds. Quality auditor shows the effect of a negative relationship to the yield to maturity of the bonds.
\end{abstract}

Keywords: Audit Committee, company size, debt to equity ratio, auditor's quality, Bank Indonesia interest rate, yield to maturity.

\begin{abstract}
Abstrak: Penelitian ini adalah untuk melakukan analisis dan mendapatkan bukti empiris mengenai pengaruh faktor internal dan faktor eksternal perusahaan terhadap yield to maturity obligasi. Faktor internal perusahaan terdiri dari komiteaudit, ukuran perusahaan, debt to equity ratio sedangkan faktor eksternal perusahaan adalah kualitas auditor dan tingkat suku bunga Bank Indonesia.Penelitian ini menggunakan 33 perusahaan yang menerbitkan obligasi pada periode 2011-2013.Data dianalisis dengan menggunakan regresi linear berganda di mana sebelumnya telah dilakukan uji asumsi klasik.Dari hasil penelitian diperoleh hasil bahwa faktor internal yang terdiri dari komite audit, ukuran perusahaan, dan debt to equity ratio tidak berpengaruh signifikan terhadap yield to maturity obligasi.Ukuran perusahaan menunjukkan hasil pengaruh yang negatif terhadap yield to maturity obligasi.Faktor eksternal perusahaan yaitu kualitas auditor dan tingkat suku bunga Bank Indonesia berpengaruh signifikan terhadap yield to maturity obligasi.Kualitas auditor menunjukkan pengaruh hubungan yang negatif terhadap yield to maturity obligasi.
\end{abstract}

Kata kunci: Komite audit (KOM), ukuran perusahaan (UKPER), debt to equity ratio (DER), Kualitas auditor (KUA), tingkat suku bunga Bank Indonesia (BI), yield to matur

\section{PENDAHULUAN}

Perusahaan di dalam menjalankan operasional usahanya membutuhakan sumber dana yang digunakan untuk membiayai kegiatan sehari-hari atau kegiatan operasional 
perusahaan, melakukan investasi, serta mengembangkan usahanya. Perusahaan yang didirikan juga mempunyai tujuan di mana perusahaan tersebut akan menjalankan usahanya dalam jangka waktu panjang dan dijalankan secara berkesinambungan dan dijalankan dengan asumsi going concern. Sumber dana yang diperoleh perusahaan bisa berasal dari pemegang saham sebagai modal awal bagi perusahaan, berasal dari pendapatan atau penjualan yang dihasilkan oleh perusahaan, serta berasal dari pihak ketiga baik berupa pinjaman yang diperoleh dari kreditur dan penerbitan surat utang atau obligasi.

Obligasi yang diterbitkan merupakan surat utang yang diterbitkan oleh perusahaan yang digunakan sebagai salah satu sumber pembiayaan perusahaan terutama untuk perusahaan publik. Tandelilin (2010: 40) menyatakan bahwa obligasi merupakan sertifikat atau surat berharga yang berisi kontrak antara investor sebagai pemberi dana dengan penerbitnya sebagai peminjam dana.

Perusahaan menerbitkan obligasi dengan memberikan return atau tingkat pengembalian yang cukup tinggi sehingga dapat menjadi daya tarik bagi investor. Nanik Indarsih (2013) menyatakan bahwa minat investor asing terhadap obligasi korporasi semakin tinggi karena yield obligasi korporasi juga tinggi. Dalam obligasi, yield dapat dikatakan sebagai return atau tingkat pengembalian yang akan diterima oleh investor pada saat jatuh tempo. Investor mengukur yield dalam investasi obligasi dengan menggunakan pengukuran yield to maturity. Hartono (2010: 164) menyatakan bahwa yield to maturity adalah sebagai tingkat return majemuk yang akan diterima investor jika membeli obligasi pada harga pasar saat ini dan menahan obligasi tersebut hingga saat jatuh tempo.

Dalam menjalankan kegiatan operasionalnya, pemilik perusahaan atau pemegang saham perusahaan akan menunjuk tenaga profesional atau agen untuk memenuhi tujuan perusahaan dan pemegang saham. Teori keagenan (agency theory) menjelaskan adanya dua kepentingan antara pemilik perusahaan dengan tenaga profesional tersebut. Dalam hubungankeagenan maka memiliki kontrak dimana principal memerintah orang lain (tenaga profesional) sebagai agen untuk melakukan suatu jasa dan memberikan wewenangkepadanya untuk mengambil suatu keputusan yang terbaik bagi prinsipal dan kemajuan perusahaan. Pemilik perusahaan akan melakukan pengawasan terhadap proses yang terjadi dalam perusahaan dan akan menunjuk auditor independen untuk memberikan pendapat atas kewajaran suatu laporan keuangan dan sebagai salah satu cara untuk mencegah terjadinya konflik keagenan.

Penelitian dilakukan pada perusahaan-perusahaan yang terdaftar di Bursa Efek Indonesia (BEI) yang menerbitkan obligasi pada periode tahun 2011-2013. Beberapa penelitian terdahulu sudah pernah dilakukan seperti Saajeev Bhojraj dan Partha Sengupta (2003) menyatakan bahwa ukuran perusahaan berpengaruh negatif dan signifikan terhadap yield obligasi, debt to equity ratio berpengaruh positif dan signifikan terhadap yield obligasi. Norpratiwi dan Setyapurnama (2004) menyatakan bahwa keberadaan komite audit berpengaruh negatif dan signifikan terhadap yield obligasi karena peran komite audit sangat penting yang mempengaruhi kinerja obligasi. Raman dan Wilson (1994) melakukan pengujian pengaruh kualitas auditor terhadap yield obligasi dengan menunjukkan hasil yang negatif. Riska Ayu Hapsari (2013) menyatakan bahwa good corporate governance tidak berpengaruh signifikan terhadap yield to maturity obligasi sedangkan ukuran perusahaan dan debt to equity ratio berpengaruh signifikan terhadap yield to maturity obligasi.

Berdasarkan penelitian-penelitian sebelumnya di atas yang menunjukkan adanya ketidak konsistenan dengan hasil yang diperoleh, maka penelitian ini dilakukan untuk 
melakukan pengujian dan analisis pengaruh faktor internal dan eksternal terhadap yield to maturity obligasi korporasi yang terdaftar di Bursa Efek Indonesia (BEI).

\section{KAJIAN TEORI}

Teori Keagenan (Agency Theory). Ardiyos (2013: 26) menyatakan bahwa teori keagenan (agency theory) merupakan hubungan antara dua pihak, yaitu sebagai prinsipal (pemberi amanat) dan pihak lainnya yaitu perantara (amanat) yang mewakili prinsipal dalam melaksanakan transaksi keuangan dengan pihak ketiga. Dalam teori ini, agen adalah sebagai pelaksana tugas di mana agen diberikan mandat atau kepercayaan oleh principal untuk memberikan jasa bagi pemilik dengan menjalankan bisnis perusahaan demi kepentingan pemilik atau principal. Dalam proses untuk menjalankan tugas dan untuk memenuhi kepentingan pemilik tersebut, sering terjadi konflik keagenan antara pemilik perusahaan dengan manajer selaku agen yang terutama disebabkan adanya perbedaan kepentingan antara agen dengan principal. Konflik juga terjadi terutama karena pemilik tidak dapat selalu memonitor setiap aktivitas manajer sehari-hari dalam menjalankan operasional bisnis perusahaan untuk memastikan bahwa pihak manajemen telah bekerja sesuai dengan keinginan pemilik atau principal.

Jensen dan Meckling (1976) menjelaskan adanya agency cost yang timbul karena adanya konflik antara pemilik dengan agen. Dalam mengatasi konflik yang terjadi, maka dibutuhkan pihak ketiga sebagai pihak yang independen yaitu auditor eksternal yang diharapkan dapat memberikan penilaian dan pendapat yang independen mengenai kewajaran suatu laporan keuangan Perusahaan. Jensen (1986) dalam Harjito (2012 : 100) berpendapat bahwa kebijakan penerbitan hutang dapat digunakan perusahaan sebagai alat untuk mendisiplinkan manajer karena harus bekerja lebih keras untuk dapat membayar kembali hutang dan bunganya.

Definisi Laporan Keuangan.Ikatan Akuntan Indonesia (2012: 1) menyatakan bahwa laporan keuangan adalah:

"laporan keuangan merupakan bagian dari proses pelaporan keuangan. Laporan keuangan yang lengkap biasanya meliputi neraca, laporan laba rugi, laporan perubahan posisi keuangan (yang dapat disajikan dalam berbagai cara, misalnya sebagai laporan arus kas atau laporan arus dana), catatan dan laporan lain, serta materi penjelasan yang merupakan bagian integral dari laporan keuangan. Disamping itu juga termasuk skedul dan informasi tambahan yang berkaitan dengan laporan tersebut, misalnya, informasi keuangan segmen industri dan geografis serta pengungkapan pengaruh perubahan harga.”

Tujuan Laporan Keuangan. Menurut Ikatan Akuntan Indoneia dalam Standar Akuntansi Keuangan (SAK 2007:3), menyatakan tujuan laporan keuangan adalah: (1) Menyediakan informasi yang menyangkut posisi keuangan, kinerja, serta perubahan posisi keuangan suatu perusahaan yang bermanfaat bagi sejumlah besar pengguna dalam pengambilan keputusan ekonomi;(2) Untuk memenuhi kebutuhan bersama sebagian besar pengguna, namun laporan keuangan tidak menyediakan semua informasi yang mungkin dibutuhkan pengguna dalam pengambilan keputusan ekonomi karena secara umum menggambarkan pengaruh keuangan dari kejadian di masa lalu, dan tidak diwajibkan untuk menyediakan informasi nonkeuangan;(3) Laporan keuangan menunjukkan apa yang 
telah dilakukan manajemen (stewardship), atau pertanggungjawaban manajemen atas sumber daya yang dipercayakan kepadanya. Pengguna ingin menilai apa yang telah dilakukan atau pertanggungjawaban manajemen agar mereka dapat membuat keputusan ekonomi.

Pengguna Laporan Keuangan dan Kebutuhan Informasi.Laporan Keuangan yang dibuat dan dipublikasikan oleh manajemen Perusahaan akan digunakan oleh banyak pihak baik internal maupun pihak eksternal. Para pengguna laporan keuangan ini menggunakan laporan keuangan untuk memenuhi beberapa kebutuhan informasi yang berbeda.

Menurut Ikatan Akuntan Indonesia dalam Standar Akuntansi Keuangan (SAK 2007:

2-3) Kebutuhan Informasi keuangan tersebut meliputi: (a) Investor, membutuhkan informasi untuk membantu menentukan apakah harus membeli, menanam, atau menjual investasi tersebut. Pemegang saham juga tertarik pada informasi; (b) yang memungkinkan mereka untuk menilai kemampuan perusahaan membayar dividen; (c) Karyawan, menggunakan laporan keuangan untuk menilai kemampuan perusahaan dalam memberikan balas jasa, imbalan pasca kerja, dan kesempatan kerja; (d) Pemberi pinjaman, menggunakan informasi keuangan untuk memutuskan apakah pinjaman serta bunganya dapat dibayar pada saat jatuh tempo;(e) Pemasok dan kreditur usaha lainnya, mereka tertarik dengan informasi yang memungkinkan mereka untuk memutuskan apakah jumlah yang terutang akan dibayar pada saat jatuh tempo;(f) Pelanggan, berkepentingan dengan informasi mengenai kelangsungan hidup perusahaan, terutama kalau mereka terkait dengan perjanjian jangka panjang dengan, atau bergantung pada perusahaan; (g) Pemerintah, membutuhkan informasi untuk mengatur aktivitas perusahaan, menetapkan kebijakan pajak, dan sebagai dasar untuk menyusun statistik pendapatan nasional dan statistik lainnya;(h) Masyarakat, laporan keuangan dapat membantu masyarakat dengan menyediakan informasi kecenderungan (tren) dan perkembangan terakhir kemakmuran perusahaan serta rangkaian aktivitasnya.

Faktor Internal dan Eksternal perusahaan. Dalam menjalankan bisnisnya, perusahaan akan berhadapan dengan lingkungan bisnis, yaitu segala sesuatu yang mempengaruhi aktivitas bisnis dalam suatu perusahaan.Faktor - faktor yang mempengaruhi tersebut tidak hanya dalam perusahaan (intern), namun juga dari luar (ekstern).

Faktor internal adalah faktor atau segala sesuatu yang berasal dari dalam perusahaan. Dalam penelitian ini, faktor-faktor internal yang mempengaruhi yield to maturity obligasi korporasi yaitu: ukuran perusahaan, Debt to Equity Ratio, komite audit.

Perama. Ukuran perusahaan.Bhojraj dan Sengupta (2003) menyatakan bahwa ukuran perusahaan menunjukkan besarnya skala ekonomi yang dimiliki oleh suatu perusahaan.Besar (ukuran) perusahaan dapat dinyatakan dalam total aktiva, penjualan dan kapitalisasi pasar. Semakin besar total aktiva, penjualan dan kapitalisasi pasar maka semakin besar pula ukuran perusahaan tersebut. Ukuran perusahaan diukur dengan menggunakan logaritma dari total asset. Kedua. Debt to Equity Ratio. Kasmir (2009) dalam bukunya “Analisis Laporan Keuangan” menyatakan bahwa rasio hutang terhadap aset diukur dengan perbandingan antara total utang dengan total aktiva. Ketiga. Komite audit. Peraturan BAPEPAM (Badan Pengawas Pasar Modal) dalam peraturan nomor IX.I.5 menyatakan bahwa komite audit adalah komite yang dibentuk oleh dan bertanggung jawab kepada dewan komisaris. Komite audit menjalankan tugas dan fungsi secara independen dalam rangka membantu dan menjalankan fungsi dewan komisaris. Komite 
audit diangkat dan diberhentikan oleh dewan komisaris dan dilaporkan dalam RUPS (Rapat Umum Pemegang Saham) perusahaan.

Faktor eksternal perusahaan adalah faktor atau segala sesuatu yang berasal dari luar perusahaan.Faktor eksternal perusahaan yang berpengaruh tidak langsung terhadap kegiatan perusahaan.Faktor eksternal meliputi variabel-variabel di luar organisasi yang dapat berupa tekanan umum dan tren di dalam lingkungan societal ataupun faktor-faktor spesifik yang beroperasi di dalam lingkungan kerja (industri) organisasi.Dalam penelitian ini, faktor-faktor eksternal yang mempengaruhi yield to maturity obligasi korporasi yaitu: kualitas auditor dan tingkat suku bunga Bank Indonesia. Keempat. Kualitas Auditor. Agoes (2012 : 2) menyatakan bahwa auditing memberikan nilai tambah bagi laporan keuangan perusahaan, karena akuntan publik pada akhir pemeriksaannya memberikan pendapat mengenai kewajaran laporan keuangan. Auditor merupakan salah satu mekanisme untuk dapat mengendalikan perilaku manajemen untuk bertindak sesuai dengan kepentingan sendiri. Kualitas sebuah pekerjaan sangat erat hubungannya dengan apa yang dilakukan seseorang di dalam pekerjaannya dan hasil pekerjaannya. Dua laporan akuntan publik yang dihasilkan dari satu kantor akuntan yang sama bisa memiliki kualitas yang berbeda.Carcello, et.al. (1992) menyatakan bahwa atribut yang harus dimiliki oleh auditor yang berkualitas menjadi 12 hal yaitu: berpengalaman, keahlian dalam industri klien, responsif terhadap kebutuhan klien, memiliki kompetensi secara teknis, Independen, bersikap hati-hati (exercised due care), komitmen terhadap kualitas, melibatkan rekan/manajer KAP dalam penugasan audit, melaksanakan pekerjaan lapangan dengan layak, berinteraksi dengan komite audit klien, mempunyai standar etika yang tinggi dan pengetahuan akuntansi dan auditing, dan bersikap skeptis dalam penugasan audit. Bukti empiris telah membuktikan bahwa terdapat perbedaan kualitas audit yang dilakukan oleh KAP. Ukuran KAP dalam hal ini dibedakan menjadi KAP besar (big 4 accounting firms) dan KAP kecil (Non big 4 accouting firms). Perbedaan tersebut berdasarkan jumlah klien yang dimiliki, jumlah rekan/anggota yang bergabung, dan total pendapatan yang diperoleh satu periode. Semakin besar sebuah KAP, semakin besar sumber daya yang dimilikinya. Sumber daya yang lebih besar diekspektasi memiliki hubungan dengan kualitas audit yang juga baik. Kelima. Tingkat Suku Bunga Bank Indonesia. Konsep suku bunga Bank Indonesia mengacu kepada tingkat suku bunga kebijakan yang mencerminkan sikap atau stance kebijakan moneter yang ditetapkan oleh bank Indonesia dan diumumkan kepada publik. Secara sederhana, BI Rate merupakan indikasi level suku bunga jangka pendek yang diinginkan Bank Indonesia dalam upaya mencapai target inflasi. Mekanisme penggunaan BI rate dalam operasi moneter adalah untuk mengarahkan agar suku bunga Sertifikat Bank Indonesia (SBI) bulan yang dilelang di Operasi Pasar Terbuka (OPT) oleh Bank Indonesia berada di sekitar BI rate. Dengan demikian diharapkan selanjutnya BI rate tersebut akan mempengaruhi suku bunga Pasar Uang Antar Bank (PUAB), suku bunga simpanan dan suku bunga lainnya termasuk suku bunga kredit. Bank Indonesia melakukan penyesuaian tingkat suku bunga (BI rate) dengan tujuan yaitu menjaga inflasi (BI rate dinaikkan untuk memperketat jumlah uang beredar sehingga gejolak inflasi bisa ditahan) dan untuk mengatur defisit transaksi berjalan.

Definisi Obligasi. Ardiyos (2013 : 62) menyatakan bahwa obligasi adalah suatu kontrak tertulis yang mendukung suatu pinjaman jangka panjang dan berbunga. Tandelilin (2010 : 245) menyatakan bahwa obligasi adalah sekuritas yang diterbitkan oleh perusahaan yang menjanjikan kepada pemegangnya pembayaran sejumlah uang tetap pada suatu tanggal jatuh tempo di masa mendatang disertai dengan pembayaran bunga secara periodik. 
Pokok pinjaman (principal) obligasi merupakan jumlah tetap yang dibayar pada waktu jatuh tempo (maturity), yang juga disebut nilai nominal atau nilai par (par value atau face value). kupon (coupon) merupakan pembayaran bunga secara periodik.

Jenis-jenis obligasi.Tandelilin (2010: 247) menyatakan obligasi perusahaan memiliki jenis yang berbeda dengan masing-masing karakakteristik yang berbeda, yaitu: (1) Obligasi dengan jaminan (mortgage bond) adalah obligasi yang diterbitkan perusahaan dengan menggunakan jaminan suatu aset real, sehingga jika perusahaan gagal memenuhi kewajibannya, pemegang obligasi berhak untuk mengambil alih aset tersebut;(2) Obligasi tanpa jaminan (debentures atau unsecured bond) adalah obligasi yang diterbitkan tanpa menggunakan suatu jaminan aset real tertentu; (3) Obligasi konversi adalah obligasi yang memberikan hak kepada pemegangnya untuk mengkonversikan obligasi tersebut dengan sejumlah saham perusahaan pada harga yang telah ditetapkan; (4) Obligasi yang disertai warrant. Dengan adanya warrant, pemegang obligasi mempunyai hak untuk membeli saham perusahaan pada harga yang telah ditentukan; (5) Obligasi tanpa kupon (zero coupon bond) adalah obligasi yang tidak memberikan pembayaran bunga. Obligasi tanpa kupon umumnya ditawarkan pada harga dibawah nilai parnya, sehingga investor memperoleh keuntungan dari nilai perbedaan harga pasar dan nilai par obligasi pada saat obligasi tersebut dibeli; (6) Obligasi dengan tingkat bunga mengambang (floating rate bond) adalah obligasi yang memberikan bunga yang besarnya disesuaikan dengan fluktuasi tingkat bunga pasar yang berlaku; (7) Putable bond adalah obligasi yang memberikan hak kepada pemegang obligasi untuk menerima pelunasan obligasi sesuai dengan nilai par sebelum waktu jatuh tempo; (8) Junk bond adalah obligasi yang memberikan tingkat keuntungan atau kupon yang tinggi, tetapi mengandung risiko yang tinggi juga; (9) Sovereign bond adalah obligasi yang diterbitkan oleh suatu Negara dengan mata uangnya sendiri, tetapi dijual di Negara lain dengan mata uang Negara tersebut.

Yield to Maturity. Yieldsuatu obligasi memiliki 3 jenis ukuran yang sering digunakan, menurut Manurung dan Tobing (2010 : 24) yaitu yield sekarang (current yield), yield sampai jatuh tempo (yield to maturity), dan yield to call (yield untuk membeli kembali). Tiga yield ini sering digunakan oleh investor atau pihak lain dalam membeli obligasi. Menurut Ardiyos (2013 : 644), yang dimaksud dengan yield to maturity adalah:

"tingkat diskonto yang menyamakan harga pasar yang berlaku dengan nilai sekarang dari arus kas masuk (cash inflows) yang diharapkan masa mendatang atau tingkat bunga tahunan yang diperoleh dari surat berharga yang dibeli pada hari tertentu dan ditahn hingga waktu jatuh tempo.”

Yield to maturity menurut Tandelilin (2010 : 259) adalah sebagai tingkat return majemuk yang akan diterima investor jika membeli obligasi pada harga pasar saat ini dan menahan obligasi tersebut hingga jatuh tempo. Guinan (2009 : 397) menyatakan bahwa yield to maturity adalah tingkat pengembalian obligasi yang diharapkan jika dipegang sampai waktu jatuh tempo.

Kerangka Berpikir. Variabel yang digunakan dalam penelitian ini terdiri dari enam variabel, dimana terdapat lima variabel independen dan satu variabel dependen. Variabel merupakan suatu gejala yang memiliki nilai yang bervariasi dan variasi tersebut dinyatakan dalam bentuk angka. Variabel independen merupakan variabel yang tidak 
dipengaruhi oleh variabel lain, sedangkan variabel dependen adalah variabel yang dipengaruhi oleh variabel independen.

Variabel independen dalam penelitian ini adalah faktor internal perusahaan yaitu komite audit, ukuran perusahaan, debt to equity ratio dan faktor eksternal perusahaan yaitu kualitas auditor dan tingkat suku bunga Bank Indoensia. Variabel independen dalam penelitian ini adalah yield to maturity obligasi. Di bawah ini adalah identifikasi variabel sebagai berikut: (a) Yield to maturity. Yield to maturity merupakan tingkat diskonto yang menyamakan harga pasar yang berlaku dengan nilai sekarang dari arus kas masuk (cash inflows) yang diharapkan masa mendatang atau tingkat bunga tahunan yang diperoleh dari surat berharga yang dibeli pada hari tertentu dan ditahan hingga waktu jatuh tempo; (b) Komite audit. Komite audit merupakan komite yang dibentuk oleh dewan komisaris untuk melakukan tugas pengawasan pengelolaan perusahaan; (c) Ukuran perusahaan. Ukuran perusahaan merupakan ukuran berdasarkan jumlah aset yang dimiliki perusahaan.Ukuran perusahaan diukur dengan menghitung logaritma natural dari jumlah aset perusahaan; (d) Debt to equity ratio. Debt to Equity Ratio merupakan ukuran leverage keuangan perusahaan, dihitung dengan membagi total ekuitas atau modal pemegang saham; (e) Kualitas auditor. Auditing menurut Agoes (2012: 2), memberikan nilai tambah bagi laporan keuangan perusahaan, karena akuntan publik pada akhir pemeriksaannya memberikan pendapat mengenai kewajaran laporan keuangan; (f) Tingkat suku bunga Bank Indonesia. BI Rate merupakan indikasi level suku bunga jangka pendek yang diinginkan Bank Indonesia dalam upaya mencapai target inflasi. Kemudian BI rate tersebut akan mempengaruhi suku bunga Pasar Uang Antar Bank (PUAB), suku bunga simpanan dan suku bunga lainnya termasuk suku bunga kredit. Bank Indonesia melakukan penyesuaian tingkat suku bunga (BI rate) dengan tujuan yaitu menjaga inflasi (BI rate dinaikkan untuk memperketat jumlah uang beredar sehingga gejolak inflasi bisa ditahan) dan untuk mengatur defisit transaksi berjalan.

Hipotesis yang dilakukan dalam penelitian ini yaitu:

$\mathrm{H}_{1}=$ terdapat pengaruh positif dan tidak signifikan antara faktor internal perusahaan terhadap Yield To Maturityobligasi yang diterbitkan perusahaan yang terdaftar di BEI tahun 2011-2013.

$\mathrm{H}_{2}=$ terdapat pengaruh positif dan signifikan antara faktor eksternal perusahaan terhadap Yield To Maturity obligasi yang diterbitkan perusahaan yang terdaftar di BEI tahun 2011-2013.

\section{METODE}

Populasi dan Teknik Pemilihan Sampel. Sugiyono (2012 : 61) menyatakan bahwa populasi adalah wilayah generalisasi yang terdiri atas obyek atau subyek yang mempunyai kualitas dan karakteristik tertentu yang ditetapkan oleh peneliti untuk dipelajari dan kemudian ditarik kesimpulannya.Bursa Efek Indonesia merupakan tempat penelitian penulis di mana BEI merupakan tempat yang memiliki sumber informasi memadai.Populasi dalam penelitian ini adalah perusahaan yang menerbitkan obligasi yang terdaftar pada Indonesia Bond Market Directory (IBMD) tahun 2011-2013.Metode pengumpulan data dilakukan dengan menggunakan metode pengambilan sampel purposive yaitu pemilihan sampel dengan kriteria tertentu.Populasi dalam penelitian ini berjumlah 94 perusahaan. Kriteria sampel dalam penelitian ini adalah: (a) Perusahaan yang menerbitkan obligasi yang tercatat di Indonesia Bond Market Directory yang 
diterbitkan oleh BEI selama tahun 2011 sampai 2013;(b) Perusahaan menerbitkan obligasi yang masih beredar atau belum jatuh tempo pada periode penelitian sehingga diperoleh harga obligasi yang berlaku; (c) Perusahaan yang menerbitkan obligasi dengan menggunakan mata uang Rupiah; (d) Perusahaan memiliki data harga obligasi yang berlaku; (e) Perusahaan yang menerbitkan obligasi, mempunyai laporan keuangan tahunan yang lengkap selama periode pengamatan dan laporan keuangan tersebut telah diaudit oleh kantor akuntan publik.

Teknik Pengolahan Data. Pada penelitian ini penulis menggunakan beberapa alat analisis data statistik adalah sebagai berikut: Pertama. Statistik Deskriptif, analisis ini digunakan untuk menggambarkan karakteristik sampel yang diujikan. Analisis ini menghitung nilai Min, Max, Mean, Standar Deviasi, dan Variansinya. Kedua. Uji Asumsi Klasik, uji Normalitas Data, bertujuan untuk menguji apakah model regresi, variabel dependen dan variabel independen keduanya mempunyai distribusi normal/mendekati normal. Uji normalitas dapat dilaksanakan dengan melihat besaran Kolmogorov Smirnov. Dengan tingkat signifikan sebesar 0,05 maka kesimpulan yang dapat diambil adalah: 1) jika pvalue (dalam hal ini Asymp. Sig-2 Tailed) > 0,05 artinya Ho dan Ha ditolak (data terdistribusi secara normal); 2) jika p-value (dalam hal ini Asymp. Sig-2 Tailed) $<0,05$ artinya Ho ditolak dan Ha diterima. Ketiga. Uji Multikolinieritas, bertujuan untuk menguji apakah model regresi ditemukan adanya korelasi antar variabel bebas (variabel independen). Model uji regresi yang baik adalah yang tidak terjadi multikolinieritas yaitu model yang mempunyai nilai VIF $<10$ dan nilai tolerance $>0,1$ atau diatas $10 \%$. Keempat. Uji Heteroskedastisitas, bertujuan untuk menguji apakah dalam sebuah model regresi, terjadi ketidaksamaan varians dari residual dari satu pengamatan ke pengamatan lain. Jika varians dari residual dari satu pengamatan ke pengamatan yang lain tetap, maka disebut homokedastisitas. Dan jika varians berbeda, disebut heteroskedastisitas.Model yang baik adalah tidak terjadinya heteroskedastisitas. Kelima Uji Autokorelasi. Nugroho (2005: 59) mengatakan bahwa uji autokorelasi bertujuan untuk menguji apakah pada suatu model regresi linier ada korelasi antar kesalahan pengganggu pada periode satu dengan periode sebelumnya.Model regresi yang baik adalah regresi yang bebas dari autokorelasi.Pengujian autokorelasi dalam penelitian ini menggunakan Durbin Watson.

Teknik Pengujian Hipotesis. Pengujian hipotesis bertujuan untuk mengetahui hipotesis yang telah diajukan dalam penelitian ini diterima atau ditolak. Teknik pengujian hipotesis ini meliputi: Pertama. Regresi Berganda. Pengujian terhadap hipotesis yang diajukan dilakukan dengan metode regresi berganda.Metode regresi berganda digunakan untuk mengetahui pengaruh dari keempat variabel independen terhadap variabel dependen. Persamaan regresi berganda adalah sebagai berikut:

$$
\mathrm{YTM}=\beta 0+\beta 1 \mathrm{KOMA}+\beta 2 \mathrm{UP}+\beta 3 \mathrm{DER}+\beta 4 \mathrm{KUA}+\beta 5 \mathrm{BI}+\varepsilon
$$

Dimana: YTM = yield to maturity obligasi ; $\beta 0=$ konstanta; $\beta 1-\beta 4=$ koefisien regresi KOMA = komite audit; UP = ukuran perusahaan; DER = debt to equity ratio; KUA $=$ kualitas auditor; $\mathrm{BI}=$ tingkat suku bunga bank indonesia; $\varepsilon=$ residual

Kedua. Pengujian secara simultan (uji F). Uji F bertujuan untuk menunjukkan apakah semua variabel bebas mempunyai pengaruh secara simultan terhadap variabel dependen. Pengujian ini dilakukan dengan menggunakan tingkat signifikansi sebesar 0,05. Nilai 
signifikansi yang dihasilkan lebih dari 0,05, maka Ha ditolak, yang menunjukkan bahwa variabel independen tersebut secara simultan tidak mempunyai pengaruh yang signifikan terhadap variabel dependen. Nilai signifikansi yang dihasilkan kurang dari 0,05, maka Ha diterima, yang menunjukkan variabel independen tersebut secara simultan mempunyai pengaruh yang signifikan terhadap variabel dependen. Ketiga. Pengujian terhadap regresi parsial (uji t). Priyatno (2012:68) menyatakan bahwa uji ini digunakan untuk menguji besarnya pengaruh variabel independen terhadap variabel dependen.Tingkat signifikan yang ditetapkan adalah 5\% atau tingkat keyakinan dalam penelitian ini adalah 95\%. Keputusan ditentukan untuk menerima atau menolak hipotesis telah dirumuskan adalah sebagai berikut: a). Nilai signifikan $<0.05$, maka H0 ditolak dan Ha diterima. Dengan kata lain, suatu variabel bebas secara individu mempunyai pengaruh signifikan terhadap variabel dependen. b). Nilai signifikan $>0.05$, maka H0 diterima dan Ha ditolak. Dengan kata lain, suatu variabel bebas secara individu tidak mempunyai pengaruh signifikan terhadap variabel dependen. Keempat. Uji Koefisien Korelasi (Uji R). Priyatno (2012 : 134) menyatakan bahwa koefisien korelasi menunjukan nilai korelasi yaitu korelasi antara dua atau lebih variabel independen terhadap variabel dependen. Nilai R berkisar antara 0 sampai 1, jika mendekati 1 maka hubungan semakin kuat tetapi jika mendekati 0 maka hubungan semakin lemah. Kelima. Uji Koefisien Determinasi (Uji R2). Koefisien determinasi menujukkan seberapa besar presentase variasi variabel independen yang digunakan dalam model mampu menjelaskan variasi variabel dependen (Priyatno, 2012: 134). Pengambilan keputusan untuk koefisien determinasi adalah: (a) Nilai koefisien determinasi yang mendekati angka satu berarti variabel independen memberikan hampir semua informasi untuk memprediksi variasi variabel independen; (b) Nilai koefisien determinasi yang mendekati angka nol berarti kemampuan variabel independen untuk memprediksi variasi variabel dependen amat terbatas.

\section{HASIL DAN PEMBAHASAN.}

Penelitian ini dilakukan untuk melihat pengaruh faktor internal perusahaan yang terdiri dari komite audit, ukuran perusahaan, debt to equity ratio dan faktor eksternal perusahaan yang terdiri dari kualitas auditor dan tingkat suku bunga Bank Indonesia terhadap yield to maturity obligasi yang diterbitkan oleh perusahaan yang tercatat di Bursa Efek Indonesia tahun 2011-2013. Berikut adalah daftar kriteria yang dijadikan sampel pada tabel 1 dibawah ini:

Tabel 1. Kriteria Pengambilan Sampel Penelitian

\begin{tabular}{lc} 
Kriteria & Jumlah \\
\hline Perusahaan yang terdaftar di Indonesia Bond Market & \\
Directory (IBMD) tahun 2011-2013 & 94 \\
Perusahaan yang tidak menerbitkan obligasi tahun 2011. & $(58)$ \\
Perusahaan yang tidak menggunakan & $(1)$ \\
mata uang rupiah & $(1)$ \\
Perusahaan tidak memiliki data obligasi yang lengkap & $(1)$ \\
Peneliti tidak memperoleh data laporan keuangan tahunan & 33 \\
Jumlah sampel & 99 \\
Jumlah sampel selama 3 tahun & \\
Sumber: Data yang diolah &
\end{tabular}


Pengujian Asumsi Klasik. Penelitian ini menggunakan analisis linier berganda untuk menguji pengaruh antara faktor internal yaitu KOM, UKPER, DER dan faktor eksternal yaitu KUA, BI terhadap Yield To Maturityobligasi. Sebelum dilakukan pengujian terhadap kelayakan suatu model regresi berganda, akan dilakukan uji asumsi klasik yaitu uji normalitas, uji multikolinieritas, uji heteroskedastisitas, dan uji autokorelasi.

Uji Normalitas. Pengujian ini untuk melihat apakah data mempunyai distribusi atau penyebaran secara normal atau tidak.Model regresi yang baik memiliki data yang terdistribusi secara normal.Pengujian ini dilakukan melalui uji Kolmogorov-Smirnov (KS).Hasil pengujian normalitas dapat dilihat pada tabel 2.

Tabel 2. Uji Normalitas

One-Sample Kolmogorov-Smirnov Test

\begin{tabular}{llr}
\hline & & Unstandardized \\
& & Residual \\
\hline $\mathrm{N}$ & Mean & 99 \\
Normal Parameters & Stb & .0000000 \\
& Std. Deviation & 1.00665609 \\
Most Extreme Differences & Absolute & .091 \\
& Positive & .091 \\
& Negative & -.058 \\
Kolmogorov-Smirnov Z & & .910 \\
Asymp. Sig. (2-tailed) & & .379 \\
\hline a. Test distribution is Normal. & \\
b. Calculated from data. & &
\end{tabular}

Pada Tabel 2 di atas menunjukkan nilai signifikansi (Asymp.Sig 2- tailed) sebesar 0,379. Batasan-batasan untuk mengetahui normalitas harus lebih besar dari 0,05. Maka dapat disimpulkan bahwa nilai residual terdistribusi secara normal atau memenuhi asumsi klasik normalitas.

Uji Multikolinieritas. Uji ini untuk mengetahui korelasi antara setiap variabel dalam suatu model regresi.Model regresi yang baik adalah tidak terjadi multikolinieritas sempurna atau tidak memiliki korelasi atau hubungan antar variabel bebasnya.

Berdasarkan hasil uji Multikolinieritas pada Tabel 3 berikut menunjukkan nilai tolerance masing-masing variabel lebih dari 0,1 dan nilai VIF masing-masing variabel kurang dari 10 maka dapat disimpulkan bahwa tidak terjadi masalah multikolinieritas pada model regresi.

Uji Autokorelasi. Uji Autokorelasi untuk mengetahui apakah dalam suatu model linear terdapat korelasi antara kesalahan pengganggu pada periode t (periode analisis) dengan kesalahan pada periode t-1 (periode sebelumnya).Model regresi yang baik adalah model regresi yang bebas autokorelasi. Salah satu cara untuk mendeteksi autokorelasi adalah dilakukan melalui uji Durbin-Watson (DW). 
Tabel 3. Uji Multikolinieritas

Coefficients $^{\mathrm{a}}$

\begin{tabular}{lrrrrr}
\hline & \multicolumn{2}{c}{$\begin{array}{c}\text { Unstandardized } \\
\text { Coefficients }\end{array}$} & $\begin{array}{c}\text { Standardize } \\
\text { Coefficients }\end{array}$ & \multicolumn{2}{c}{$\begin{array}{c}\text { Collinearity } \\
\text { Statistics }\end{array}$} \\
\cline { 2 - 6 } Model & \multicolumn{1}{c}{ B } & Std. Error & \multicolumn{1}{c}{ Beta } & Tolerance & VIF \\
\hline 1 (Constant) & 10.728 & 3.049 & & & \\
KOM & .037 & .119 & .037 & .611 & 1.636 \\
UKPER & -.174 & .104 & -.218 & .522 & 1.915 \\
DER & .050 & .033 & .168 & .736 & 1.359 \\
KUA & -.486 & .242 & -.195 & .951 & 1.052 \\
BI & .562 & .198 & .271 & .981 & 1.019 \\
\hline
\end{tabular}

a. Dependent Variable: YTM

Tabel 4. Uji Autokorelasi

Model Summary

\begin{tabular}{llrrrr}
\hline & & & & Std. Error of the & \multicolumn{2}{c}{$\begin{array}{c}\text { Durbin- } \\
\text { Model }\end{array}$} & $\mathrm{R}$ & R Square & Adjusted R Square & Estimate & Watson \\
\hline 1 & $.413^{\mathrm{a}}$ & .170 & .126 & 1.03336 & 2.109 \\
\hline
\end{tabular}

a. Predictors: (Constant), BI, UKPER, KUA, DER, KOM

b. Dependent Variable: YTM

Pada Tabel 4 menunjukkan nilai Durbin-Watson (DW) sebesar 2,109. Nilai dU dan dL diperoleh melalui tabel statistik Durbin Watson. Dengan menggunakan tingkat signifikansi sebesar 0,05 pada $n=99$ dan $K=5$, diperoleh nilai dU sebesar 1,780 . Nilai DW 2,109 lebih besar dari batas atas (dU) 1,780 dan kurang dari (4-dU) 2.220 sehingga dapat disimpulkan bahwa tidak terdapat autokorelasi.

Uji Heteroskedastisitas. Uji ini untuk menguji apakah model regresi terjadi ketidaksamaan variance dari residual suatu pengamatan ke pengamatan yang lain. Jika variance dari residual suatu pengamatan ke pengamatan lain tetap.

Tabel 5. Uji Heteroskedastisitas Coefficients $^{\mathrm{a}}$

\begin{tabular}{|c|c|c|c|c|c|c|}
\hline \multirow{2}{*}{\multicolumn{2}{|c|}{ Model }} & \multicolumn{2}{|c|}{ Unstandardized Coefficients } & \multirow{2}{*}{$\begin{array}{c}\begin{array}{c}\text { Standardized } \\
\text { Coefficients }\end{array} \\
\text { Beta } \\
\end{array}$} & \multirow[b]{2}{*}{$\mathrm{t}$} & \multirow[b]{2}{*}{ Sig. } \\
\hline & & B & Std. Error & & & \\
\hline \multirow[t]{6}{*}{1} & (Constant) & 1.878 & 1.667 & & 1.126 & .263 \\
\hline & KOM & -.016 & .065 & -.033 & -.253 & .801 \\
\hline & UKPER & -.005 & .057 & -.012 & -.087 & .931 \\
\hline & DER & -.018 & .018 & -.118 & -.994 & .323 \\
\hline & KUA & -.133 & .132 & -.105 & -1.008 & .316 \\
\hline & $\mathrm{BI}$ & -.101 & .108 & -.096 & -.936 & .352 \\
\hline
\end{tabular}

a. Dependent Variable: RES2 
Pada Tabel 5 di atas menunjukkan nilai signifikansi masing-masing dari kelima variabel independen lebih besar dari 0,05, sehingga dapat disimpulkan bahwa tidak terjadi masalah heteroskedastisitas pada model regresi.

Pengujian Regresi Linier Berganda. Pengujian ini digunakan untuk mengetahui besarnya pengaruh variabel-variabel bebas (independen) yaitu KOM, UKPER, DER, KUA, BI terhadap variabel terikat (dependen) yaitu Yield To Maturity obligasi korporasi.

Tabel 6. Uji Regresi Linier Berganda

\begin{tabular}{|c|c|c|c|c|c|}
\hline \multirow[b]{2}{*}{ Model } & \multicolumn{2}{|c|}{$\begin{array}{c}\text { Unstandardized } \\
\text { Coefficients }\end{array}$} & \multirow{2}{*}{$\begin{array}{c}\begin{array}{c}\text { Standardized } \\
\text { Coefficients }\end{array} \\
\text { Beta } \\
\end{array}$} & \multirow[b]{2}{*}{$\mathrm{t}$} & \multirow[b]{2}{*}{ Sig. } \\
\hline & B & Std. Error & & & \\
\hline 1 (Constant) & 10.728 & 3.049 & & 3.518 & .001 \\
\hline KOM & .037 & .119 & .037 & .310 & .758 \\
\hline UKPER & -.174 & .104 & -.218 & -1.666 & .099 \\
\hline DER & .050 & .033 & .168 & 1.523 & .131 \\
\hline KUA & -.486 & .242 & -.195 & -2.008 & .048 \\
\hline BI & .562 & .198 & .271 & 2.838 & .006 \\
\hline
\end{tabular}

Berdasarkan hasil pengujian regresi linier berganda pada Tabel 6, pengaruh variabelvariabel bebas terhadap yield to maturity dapat ditentukan melalui persamaan regresi linier berganda sebagai berikut:

$\mathrm{YTM}=10,728+0,037 \mathrm{KOM}+$ 0,050DER + 0,562BI - 0,174UKPER - 0,486KUA

Dari persamaan regresi linier berganda menunjukkan bahwa tingkat suku bunga Bank Indonesia (BI) mempunyai pengaruh yang paling besar yaitu sebesar 0,562 dibandingkan dengan variabel bebas lainnya. Kemudian variabel bebas yang paling kecil pengaruhnya ada komite audit (KOM) yaitu sebesar 0,037. Variabel bebas KOM, DER, dan BI mempunyai pengaruh positif terhadap yield to maturity, yang artinya meningkatnya variabel bebas KOM, DER, BI akan menaikkan nilai yield to maturity. Sedangkan variabel bebas UKPER, KUA mempunyai pengaruh negatif yang artinya meningkatnya variabel bebas UKPER dan KUA akan mengakibatkan menurunnya nilai yield to maturity.

Uji Koefisien Determinasi. Uji koefisien determinasi $R$ square $\left(\mathrm{R}^{2}\right)$ adalah untuk mengukur berapa besar variabel independen akan mempengaruhi variabel dependen. Berdasarkan hasil pengujian determinasi $\left(\mathrm{R}^{2}\right)$ menunjukkan nilai sebesar 0,170. Hal ini berarti variabel independen akan mempengaruhi variabel dependen sebesar $17 \%$ yaitu yield to maturity akan dipengaruhi oleh KOM, UKPER, DER, KUA, BI sebesar 17\%, sisanya dipengaruhi variabel lain yang tidak termasuk dalam pengujian ini.

Uji Korelasi (R). Pengujian ini untuk mengetahui hubungan antar variabel independen dengan variabel dependen.Nilai $\mathrm{R}$ berkisar antara 0 sampai 1.Jika nilai $\mathrm{R}$ mendekati 1 , maka hubungan antar variabel semakin kuat. Sugiono (2009 : 231) memberikan pedoman dalam menginterpretasikan koefisien korelasi: a) 0.00-0.199 = sangat rendah, b) 0.20 $0.399=$ rendah, c) $0.40-0.599=$ sedang, d) 0.60-0.799 = kuat, dan e) 0.80-1.00 = sangat kuat. Hasil uji korelasi pada tabel 4 menunjukkan nilai 0.413, di mana dapat dikatakan bahwa hubungan variabel independen yaitu KOM, UKPER, DER, KUA, BI terhadap yield 
to maturity obligasi, menunjukkan hubungan yang sedang karena nilai korelasi (R) terletak antara 0.40-0.599.

Hipotesis.Hipotesis adalah jawaban atau pernyataan sementara mengenai rumusan dari penelitian yang dikemukakan dinmana masih harus dibuktikan kebenarannya di dalam kenyataannya.Dalam hipotesis diperlukan adanya asumsi dasar yang dimuat secara logis, di mana asumsi tersebut menjelaskan hipotesis yang merupakan jawaban sementara terhadap permasalahan penelitian sampai dapat dibuktikan hasilnya. Hipotesis dalam penelitian ini adalah sebagai berikut:

$\mathrm{H}_{1}=$ terdapat pengaruh positif dan tidak signifikan antara faktor internal perusahaan terhadap Yield To Maturityobligasi yang diterbitkan perusahaan yang terdaftar di BEI tahun 2011-2013.

$\mathrm{H}_{2}=$ terdapat pengaruh positif dan signifikan antara faktor eksternal perusahaan terhadap Yield To Maturity obligasi yang diterbitkan perusahaan yang terdaftar di BEI tahun 2011-2013.

Uji Statistik t. Uji statistik t menunjukkan seberapa besar pengaruh satu variabel bebas terhadap variabel terikat dengan menganggap variabel bebas lainnya adalah konstan.

Tabel 7. Uji Statistik t

\begin{tabular}{|c|c|c|c|c|c|}
\hline \multirow[b]{2}{*}{ Model } & \multicolumn{2}{|c|}{$\begin{array}{l}\text { Unstandardized } \\
\text { Coefficients }\end{array}$} & \multirow{2}{*}{$\begin{array}{c}\begin{array}{c}\text { Standardize } \\
\text { d } \\
\text { Coefficients }\end{array} \\
\text { Beta }\end{array}$} & \multirow[b]{2}{*}{$\mathrm{t}$} & \multirow[b]{2}{*}{ Sig. } \\
\hline & B & Std. Error & & & \\
\hline 1 (Constant) & 10.728 & 3.049 & & 3.518 & .001 \\
\hline $\mathrm{KOM}$ & .037 & .119 & .037 & .310 & .758 \\
\hline UKPER & -.174 & .104 & -.218 & -1.666 & .099 \\
\hline DER & .050 & .033 & .168 & 1.523 & .131 \\
\hline KUA & -.486 & .242 & -.195 & -2.008 & .048 \\
\hline BI & .562 & .198 & .271 & 2.838 & .006 \\
\hline
\end{tabular}

Berdasarkan hasil pengujian seperti ditunjukkan oleh tabel 7, nilai signifikansi pada variabel independen KOM, UKPER, DER menunjukkan nilai $>0,05$, dimana $\mathrm{H}_{1}$ diterima, yang artinya variabel independen faktor internal yang terdiri dari KOM, UKPER, DER tidak berpengaruh signifikan terhadap yield to maturity obligasi. Selain itu variabel UKPER memiliki pengaruh negatif dan tidak signifikan terhadap yield to maturity. Kemudian nilai signifikansi pada variabel faktor eksternal yaitu KUA dan BI < 0,05, yaitu $\mathrm{H}_{2}$ diterima, yang artinya variabel independen faktor eksternal yang terdiri dari KUA, BI mempunyai pengaruh signifikan terhadap yield to maturity obligasi. Variabel KUA berpengaruh negatif dan signifikan terhadap yield to maturity obligasi.

Uji Statistik F. Uji statistik F digunakan untuk menunjukkan semua variabel bebas yang digunakan dan dimasukkan ke dalam model mempunyai pengaruh secara bersamaan atau simultan terhadap variabel terikat. Nilai signifikansi yang dihasilkan lebih besar dari 0,05, maka Ha ditolak, yang artinya kelima variabel independen tersebut secara simultan tidak mempunyai pengaruh yang signifikan terhadap variabel dependen. 
Tabel 8. Uji Statistik F

\begin{tabular}{crrrrr}
\multicolumn{6}{c}{ ANOVA $^{\mathbf{a}}$} \\
Model & Sum of Squares & df & Mean Square & F & Sig. \\
\hline Regression & 20.393 & 5 & 4.079 & 3.819 & $.003^{\mathrm{b}}$ \\
1 Residual & 99.309 & 93 & 1.068 & & \\
Total & 119.702 & 98 & & & \\
\hline
\end{tabular}

a. Dependent Variable: YTM

b. Predictors: (Constant), BI, UKPER, KUA, DER, KOM

Berdasarkan hasil uji ANOVA pada Tabel 8 menunjukkan nilai F hitung sebesar 3,819 dengan nilai signifikansi sebesar 0,003. Dengan tingkat signifikansi dibawah 0,05 (0,003 $<0,05$ ) maka dapat dikatakan bahwa kelima variabel bebas yaitu KOM, UKPER, DER, KUA, BI berpengaruh signfikan terhadap yield to maturityobligasi pada tingkat keyakinan $95 \%$.

\section{PENUTUP}

Simpulan.Tujuan penelitian ini adalah untuk menguji bagaimana pengaruh faktor internal yang terdiri dari komite audit, ukuran perusahaan, debt to equity ratio dan faktor eksternal yang terdiri dari kualitas auditor dan tingkat suku bunga Bank Indonesia terhadap yield to maturity obligasi. Populasi yang digunakan dalam penelitian ini adalah seluruh perusahaan yang menerbitkan obligasi yang terdaftar di Indonesian Bond Market Directory (IBMD) periode 2011 sampai 2013.

Variabel faktor internal yang terdiri dari komite audit, ukuran perusahaan, debt to equity ratio tidak mempunyai pengaruh signifikan terhadap yield to maturity obligasi, di mana dalam hal ini walaupun semua perusahaan yang termasuk dalam sampel memiliki komite audit yang cukup banyak namun keberadaan komite audit belum mampu meningkatkan integritas dan kredibilitas laporan keuangan karena perusahaan masih cenderung tidak transparan dalam melakukan pemilihan komite audit sehingga tidak memiliki implikasi terhadap kinerja obligasi. Hasil pengujian ini bertentangan dengan penelitian yang dilakukan oleh Norpratiwi dan Setyapurnama (2004), yang menyatakan bahwa komite audit berpengaruh negatif dan signifikan.

Variabel ukuran perusahaan menunjukkan pengaruh negatif dan tidak signifikan terhadap yield to maturityobligasi, di mana hal ini dapat dikatakan bahwa perusahaan dengan ukuran besar maupun kecil akan lebih mengutamakan kewajibannya dibandingkan untuk memperluas usahanya. Hasil pengujian menunjukkan pengaruh negatif yang artinya bahwa peningkatan ukuran perusahaan akan menurunkan yield to maturityobligasi. Semakin besar perusahaan maka akan menurunkan yield to maturity obligasi, karena perusahaan semakin besar akan semakin banyak membutuhkan dana pinjaman, sehingga investor hati-hati dalam melakukan investasi dalam perusahaan besar karena semakin besar perusahaan akan semakin kompleks permasalahan yang akan dihadapi oleh perusahaan. Hasil penelitian ini bertentangan dengan dengan Hapsari (2013) dan Bhojraj dan Sengupta (2003), yang menyatakan bahwa ukuran perusahaan mempunyai pengaruh yang signifikan terhadap yield to maturity obligasi. 
Variabel debt to equity ratio tidak mempunyai pengaruh yang signifikan terhadap yield to maturity obligasi, di mana obligasi yang diterbitkan oleh perusahaan umumnya memiliki jangka waktu yang panjang, sehingga investor merasa aman karena perusahaan akan tetap membayar bunga dan hutang pokok obligasi dengan menggunakan sumber daya yang dimiliki oleh perusahaan.Hasil penelitian ini bertentangan dengan Bhojraj dan Sengupta (2003), Surya dan Nasher (2011), serta Hapsari (2013), yang menyatakan bahwa debt to equity ratio mempunyai pengaruh yang signifikan terhadap yield to maturity obligasi.

Variabel faktor eksternal yang terdiri dari kualitas auditor dan tingkat suku bunga Bank Indonesia mempunyai pengaruh signifikan terhadap yield to maturity obligasi. Dalam hal ini perusahaan yang diaudit oleh KAP big fourakan mempunyai peringkat obligasi yang cukup baik karena semakin tinggi kualitas auditor maka semakin tinggi juga tingkat kepastian mengenai kondisi keuangan perusahaan. KAP big four diyakini akan memberikan kualitas audit yang baik dan menghasilkan laporan audit yang lebih berkualitas karena memiliki sumber daya yang lebih banyak dan lebih menjaga reputasi secara internasional.Hasil penelitian ini konsisten dengan penelitian yang dilakukan oleh Raman dan Wilson (1994), yang menyatakan bahwa kualitas auditor berpengaruh signifikan terhadap yield to maturity obligasi.

Variabel tingkat suku bunga Bank Indonesia mempunyai pengaruh positif dan signifikan terhadap yield to maturity obligasi, yaitu dapat disimpulkan bahwa semakin tinggi tingkat suku bunga Bank Indonesia akan meningkatkan yield to maturity obligasi. Tingkat suku bunga yang ditetapkan oleh Bank Indonesia akan ikut mempengaruhi yield to maturityobligasi korporasi, karena pada umumnya perusahaan dalam menentukan tingkat bunga kupon obligasi akan melihat pada tingkat suku bunga yang diterbitkan oleh Bank Indonesia dan untuk menarik minat investor maka perusahaan akan memberikan tingkat bunga yang lebih tinggi dari tingkat suku bunga Bank Indonesia. Tingkat suku bunga Bank Indonesia juga umumnya digunakan sebagai dasar dalam menentukan tingkat suku bunga Sertifikat Bank Indonesia (SBI).

Saran. Dengan adanya ketidak konsistenan dari hasil penelitian dengan penelitian sebelumnya, maka untuk penelitian selanjutnya disarankan agar memperpanjang masa periode pengamatan sehingga dapat lebih menggambarkan konsistensinya. Penelitian selanjutnya agar menambahkan variabel-variabel lainnya yang mempengaruhi yield to maturity obligasi seperti rasio keuangan, tingkat suku bunga Sertifikat Bank Indonesia, dan variabel lainnya.

\section{DAFTAR RUJUKAN}

Agoes, Sukrisno,(2012) Auditing (Pemeriksaan Akuntan) oleh Kantor Akuntan Publik Edisi 4, Jakarta: Salemba Empat.

Bhojraj, Sanjeev dan Partha Sengupta, (2003) "Effect of Corporate Governance on Bond Ratings and Yields": The Role of Institutional. Chicago: Chicago Journals.

Handayani, Artini, (2013) "Pengaruh Faktor Ekonomi Makro, KeputusanInvestasi Dan Keputusan Pendanaan TerhadapYield Oligasi Korporasi Di Bursa Efek Indonesia, Bali”. Jurnal Akuntansi Dan Keuangan. Vol 1.

Hapsari, Riska Ayu, (2013) "Kajian Yield to Maturity (YTM) Obligasi Pada Perusahaan Korporasi”. Semarang: Accounting Analysis Journal.

Hartono, Jogiyanto, (2010) Teori Portofolio dan Analisis Investasi. Yogyakarta: BPFE. 
Herwiyanti, Eliada dan Zaki Baridwan, (2008) "Penagruh Kualitas Laba Pada Yields Obligasi Dengan Corporate Governance Sebagai Variabel Pemoderasi”.Yogyakarta :Jurnal Bisnis dan Akuntansi.

Ibrahim, Hadiasman,(2008) Pengaruh Tingkat Suku Bunga, Peringkat Obligasi, Ukuran Perusahaan dan Debt to Equity Ratio Terhadap Yield to Maturity Periode Tahun 2004-2006. Tesis. Universitas Diponegoro. Semarang.

Ikatan Akuntan Indonesia, (2012) Standar Akuntansi Keuangan. Jakarta: Salemba Empat. Immacullata, Restuti, (2007) Pengaruh Pertumbuhan Perusahaan Terhadap Peringkat dan Yield Obligasi. Jurnal Akuntansi dan Keuangan.1 (3): 1-20.

Indarsih, Nanik. (2013) "Pengaruh Tingkat Suku Bunga, SBI, Rating, Likuiditas, dan Maturitas Terhadap Yield to Maturity Obligasi”. Jurnal Ilmu Manajemen, 1 (1)

Kasmir, (2009) Analisis Laporan Keuangan, Edisi kesatu. Jakarta: Rajawali Pers.

Manurung, Adler Haymans dan Wilson Ruben Lumban Tobing, (2010) Obligasi: Harga Portofolio dan Perdagangannya. Jakarta : PT. Adler Manurung Press.

Masdupi, Erni, (2005) “Analisis Dampak Struktur Kepemilikan Pada Kebijakan Hutang Dalam Mengontrol Konflik Keagenan”. Journal Ekonomi dan Bisnis Indonesia, 20(1) : $57-69$.

Naluritha Sari, Abudanti, (2015) "Variabel-variabel Yang Mempengaruhi Yield Obligasi Pada Perusahaan Yang Terdaftar di Bursa Efek Indonesia”. E-jurnal Manajemen Unud, 4 (11).

Nurfauziah, Setyarini A.F, (2004) “Analisis Faktor-faktor Yang Mempengaruhi Yield Obligasi Perusahaan (Studi Kasus Pada Industri Perbankan dan Industri Finansial)”. Jurnal Siasat Bisnis. 2 (9): 241-256.

Raman, K.K dan Earl R. Wilson, (1994) "Governmental Audit Procurement Practices and Seasoned Bond Price”. The Accounting Review (Oct): 517-528.

Santoso, Singgih, (2013) Menguasai SPSS 21 di Era Informasi. Edisi 1. Jakarta: Gramedia, IKAPI.

Setyapurnama, Yudi Santara dan A.M Vianey Norpratiwi, (2006) "Pengaruh Corporate Governance Terhadap Peringkat Obligasi dan Yield Obligasi”. Jurnal Akuntansi dan Bisnis. 7 (2): 107-108.

Suaryana, Agung, (2005) Pengaruh Komite Audit Terhadap Kualitas Laba. Simposium Nasional Akuntansi 8. Solo Tanggal 15-16 September 2005.

Surya, Budhi Arta dan Teguh Gunawan Nasher, (2011) “Analisis Pengaruh Tingkat Suku Bunga SBI, Exchange Rate, Ukuran Perusahaan, Debt To Equity Ratio, dan Bond Terhadap Yield Obligasi Korporasi di Indonesia.Bandung”. Jurnal Manajemen Teknologi. 10(2). 